\title{
The Ban on Strike Action by Career Civil Servants under the German Basic Law: How the Federal Constitutional Court Constitutionally Immunized the German Legal Order Against the European Convention on Human Rights
}

\author{
Matthias Jacobs* and Mehrdad Payandeh**
}

(Received 02 April 2019; accepted 26 June 2019)

\begin{abstract}
The Federal Constitutional Court has decided that the prohibition to strike for career civil servants, as it has traditionally been part of the German legal order, is in compliance with the German Constitution. The Court thereby put a (provisional) end to a long-lasting debate on how to solve the tension between the fundamental freedom to form associations under Article 9(3) of the Basic Law, which arguably encompasses a right to strike, and Article 33(5) of the Basic Law, which protects the traditional principles of the career civil servants, which arguably encompasses the prohibition to strike. Through recognizing that the ban on strike action by career civil servants is not only allowed but required under the German Constitution, the Constitutional Court navigates the German legal order on a potential collision course with the European Convention on Human Rights and the European Court of Human Rights. In this context, the Constitutional Court on the one hand reaffirms the openness of the German constitutional order towards international law in general and human rights and the European Convention on Human Rights in particular. On the other hand, the Court somehow marginalizes the role of the European Court of Human Rights and threatens to not follow the Court should it hold that the European Convention on Human Rights demands a right to strike also for career civil servants.
\end{abstract}

Keywords: Right to strike; career civil servants; European Convention on Human Rights; Federal Constitutional Court; European Court of Human Rights

\section{A. Introduction}

On June 12, 2018, the Second Senate of the Federal Constitutional Court decided that the ban on strike action by career civil servants was constitutional. ${ }^{1}$ It thereby put a provisional end to a yearslong debate over the question of whether career civil servants have the right to strike. Within the German legal order, such a right is traditionally not recognized. Although there is no explicit prohibition for career civil servants to strike-at least not within Federal statutory law-such

\footnotetext{
${ }^{*}$ Mehrdad Payandeh is the Chair for International Law, European Law, and Public Law at Bucerius Law School in Hamburg, Germany.

${ }^{* *}$ Matthias Jacobs is the Chair for Civil Law, Labor Law, and Law of Civil Procedure at Bucerius Law School in Hamburg, Germany

${ }^{1}$ E.g., Bundesverfassungsgericht [BVerfG] [Federal Constitutional Court] June 12, 2018, 2 BvR 1738/12 [hereinafter Judgment of June 12, 2018].
} 
a right to strike is widely held to be incompatible with the traditional principles of the career civil service system as they are constitutionally protected under Article 33(5) of the Basic Law: ${ }^{2}$ As the Constitutional Court reiterates these core structural principles to include the civil servants' duty of loyalty, the principle of lifetime employment, the principle of alimentation, and the corresponding principle that remuneration of civil servants must be determined unilaterally by law. ${ }^{3}$ The basic idea behind the ban on strike action is, therefore, that the civil servant, on the one hand, has particularly crucial functions to fulfill within the state that do not allow for her or him to strike, and that, on the other hand, this constraint for the civil servants is compensated by rather far-reaching obligations of the state to provide for its civil servants. The comprehensive strike ban is, however, legally challenged from two different directions. First, under constitutional law, the question arises whether the ban is compatible with the fundamental freedom to form associations under Article 9(3) of the Basic Law. ${ }^{4}$ Second, with regard to international law, Article 11 of the European Convention on Human Rights (ECHR) also recognizes the freedom of association with others, including the right to form and to join trade unions. ${ }^{5}$ Because the European Court of Human Rights had recognized that civil servants also enjoy this right, the question of whether the comprehensive strike ban under German law was compatible with the ECHR had been subject to fierce debate at the forefront of the decision of the Constitutional Court. In its decision, the Constitutional Court, however, rejected the claims made against the strike ban, holding that it is compatible with the right to form associations both under Article 9(3) of the Basic Law and the ECHR. Nevertheless, the constitutional petrification of the strike ban arrived at by the Federal Constitutional Court in its decision must be viewed critically, not only from the perspective of constitutional law, ${ }^{6}$ but also because of its confrontational stance toward the ECHR and the European Court of Human Rights. ${ }^{7}$

\section{B. Constitutional Evaluation}

With regard to constitutional law, the Federal Constitutional Court examines the ban on strike action by career civil servants in light of the right to form associations under Article 9(3) of the Basic Law, and in light of traditional constitutional principles referring to the civil service. The latter have always included a status-based ban on civil servant strikes under Article 33(5) of the Basic Law.

\section{Scope of Protection of the Right to Form Associations}

The Court's statements about the personal and the material scope of protection of the right to form associations confirm its own previous case-law and that of the Federal Labor Court. The personal scope of protection of the right to form associations extends to all persons in their capacity as members of a given profession, with no category of professionals excluded. ${ }^{8}$ It therefore also applies to career civil servants. The material scope of protection encompasses the right to form associations, which includes the right to strike. ${ }^{9}$ All behaviors specific to associating are covered,

\footnotetext{
${ }^{2}$ Article 33(5) of the Basic Law reads: "The law governing the public service shall be regulated and developed with due regard to the traditional principles of the professional civil service."

${ }^{3}$ Judgment of June 12, 2018 at para. 120 (citing various opinions for each core structural principle).

${ }^{4}$ Article 9(3), sentence 1 of the Basic Law reads: "The right to form associations to safeguard and improve working and economic conditions shall be guaranteed to every individual and to every occupation or profession."

${ }^{5}$ Article 11(1) of the ECHR reads: "Everyone has the right to freedom of peaceful assembly and to freedom of association with others, including the right to form and to join trade unions for the protection of his interests."

${ }^{6}$ See infra Section B.

${ }^{7}$ See infra Section C.

${ }^{8}$ Judgment of June 12, 2018 at para. 113.

${ }^{9}$ Judgment of June 12, 2018 at para. 115.
} 
not just a set of core activities. The Federal Constitutional Court at first only mentions the right to strike ${ }^{10}$ but then goes on to characterize collective action by labor as a protected means, ${ }^{11}$ and it does so in a manner that one must assume that there is no predetermined inventory of protected means of collective action. ${ }^{12}$

The Federal Constitutional Court for the first time took a position on the relationship between Article 9(3) and Article 33(5) of the Basic Law. As recently as 2014, the Federal Administrative Court held that Article 33(5) of the Basic Law directly limits the scope of protection under Article 9(3) of the Basic Law. ${ }^{13}$ That view renders a balancing of these two conflicting constitutional legal positions immaterial. The Federal Constitutional Court, however, has now taken a different approach: It notes that the traditional principles of the civil service system do not preempt the right to form labor coalitions from applying in general, but they rather call for review at the level of whether they justify the impairment of this right. ${ }^{14}$ This is, in general, a convincing doctrinal approach to fundamental rights. ${ }^{15}$

In the Federal Constitutional Court's view, strikes by career civil servants are therefore within the scope of protection of Article 9(3) of the Basic Law and so deemed a protected activity within the right to form labor coalitions. ${ }^{16}$ This approach, however, is not self-explanatory. Civil servants' "working conditions" are not determined by the collective agreements that collective action typically aims to procure, but rather by laws and regulations. Now, the Federal Constitutional Court and the Federal Labor Court share the view that Article 9(3) of the Basic Law protects a greater range of activity than temporary work stoppages by those employees whose own conditions of employment will be determined by the collective agreement they are seeking. The protection extends instead to all activities specific to labor coalitions. ${ }^{17}$ After the Federal Constitutional Court in 2014 extended constitutional protection to flash-mobs when these are incidental to a strike, ${ }^{18}$ apparently it will now also hold that a sympathy strike is likewise a generally permissible means of collective action: ${ }^{19}$ To fall under the scope of protection of Article 9(3) of the Basic Law, a strike by career civils servants does not need to be aimed at extracting a collective agreement for themselves. According to the Second Senate, it is instead sufficient that the strike is led by a union and related to another collective bargaining effort. ${ }^{20}$ From the Court's point of view, the fact that a collective agreement can have no legal effect on civil servants themselves, and that they are instead seeking a spill-over effect from the public employees' union's outcome into their own compensation, has no bearing on whether the challenged activity falls within the scope of protection. If uninvolved "third parties" with no legal relationship whatsoever to the employer are permitted

\footnotetext{
${ }^{10}$ Judgment of June 12, 2018 at para. 114.

${ }^{11}$ Judgment of June 12, 2018 at para. 116.

${ }^{12}$ Bundesarbeitsgericht [BAG] [Federal Labor Court] Sept. 22, 2009, Neue Zeitschrift für ArbeITSRecht [NZA] 1347, 1351. See also Bundesverfassungsgericht [BVerfG] [Federal Constitutional Court] Mar. 3, 2014, NEUE JURISTISCHE WOCHENSCHRIFT [NJW] 1874, 1875-76 (affirming). But see Matthias Jacobs, Das neue Arbeitskampfrecht des Bundesarbeitsgerichts, ZEITSCHRIFT FÜR ARBEITSRECHT 71, 81 (2011) (criticizing the holding).

${ }^{13}$ Bundesverwaltungsgericht [BVerwG] [Federal Administrative Court] Feb. 27, 2014, 149 Entscheidungen des Bundesverwaltungsgerichts [BVerwGE] 117, 121, 125-26 (ruling in favor of a "comprehensive ban" on strikes by civil servants; the strike ban "takes precedence over the fundamental right to form labor coalitions under article 9(3) of the Basic Law").

${ }^{14}$ Judgment of June 12, 2018 at paras. 138-39.

${ }^{15}$ See also Timo Hebeler, Die Beamtenstreikentscheidung des Bundesverfassungsgerichts, ZEITSCHRIFT FÜR TARIFRECHT 368, 370 (2018) (agreeing).

${ }^{16}$ Judgment of June 12, 2018 at para. 137.

${ }^{17}$ See Judgment of June 12, 2018 at para. 115; NJW 1874 (1875); NZA 1347 (1350-51).

${ }^{18}$ NJW 1874 (1875).

${ }^{19}$ See also Paul Melot de Beauregard, Kein Streikrecht für Beamte, DER BETRIEB 1737 (2018); Mike Wienbracke, Commentary, Anmerkung, EuropäISCHE ZeITSCHRIFT FÜr WIRTSCHAFTSRECHT [EUZW] 653 (2018).

${ }^{20}$ Judgment of June 12, 2018 at para. 140.
} 
to join the labor dispute by showing up for a flash-mob incidental to a strike, then the same must apply to civil servants. ${ }^{21}$

The Federal Constitutional Court sees another conceivable objection in the "strikers" lacking "eligibility to enter into collective agreements." ${ }^{2}$ This is odd, at least from a terminological standpoint, because the strikers are neither eligible nor required to enter into collective agreements. Eligibility to enter into such agreements can only apply to labor coalitions, not to their members. Be that as it may, the strikes by the career civil servants in the case in which this decision was rendered were led by the Gewerkschaft Erziehung und Wissenschaft, a labor union eligible to enter into collective agreements.

\section{The Justification of the Impairment}

At the center of the analysis under constitutional law is the question of whether "sufficiently important interests protected by constitutional law" justify an impairment of the right. ${ }^{23}$

\section{The Strike Ban as a Traditional Principle of the Career Civil Service System}

The Federal Constitutional Court first re-elaborates that the career civil servant strike ban is an independent traditional principle of the career civil service system within the meaning of Article 33(5) of the Basic Law. ${ }^{24}$ It has been in place since the Weimar period, which makes it "customary" or "conventional," in a manner that it possesses "traditionality." The substantive quality required for the recognition of such a constitutional principle is found in the inextricable link between the strike ban and, on the one hand, the duty of loyalty imposed under career civil servant law, and, on the other hand, the principle of alimentation. The duty of loyalty purportedly requires duly appointed and sworn civil servants to set aside their own interests in the performance of the duties entrusted to them. Engaging in a labor dispute would be impossible to reconcile with this idea. The same is said to be true of alimentation: Civil servants have an obligation to put all their labor at their employer's disposal, and in turn the employer is obligated to provide them with alimentation for life.

Fundamental to the judgment - and at the same time the crux of the decision-is the sharply worded conclusion that "[a]ccording to the present constitutional concept of the career civil service system, the ban on strike action is inseparably linked to the principle of alimentation and the duty of loyalty." 25 The Court adds that a right to strike for career civil servants would be "incompatible with these two principles which are essential elements of a civil servant's functions." The strike ban under Article 33(5) of the Basic Law is rather-and once more the uncompromising language is striking - an "independent structural principle of the career civil service system," the "abandon[ment of which] would fundamentally challenge the order of the career civil service system as it exists in Germany." ${ }^{26}$ It is already clear at this point that the subsequent establishment of practical concordance between the two conflicting principles will not

\footnotetext{
${ }^{21}$ NJW 1874 (1876); NZA 1347 (1352).

${ }^{22}$ Judgment of June 12, 2018 at para. 140.

${ }^{23}$ Judgment of June 12, 2018 at para. 142.

${ }^{24}$ Judgment of June 12, 2018 at paras. 144-152; Bundesverfassungsgericht [BVerfG] [Federal Constitutional Court] June 11, 1958, 8 ENTSCHEIDUNGEN DES BUNDESVERFASSUNGSGERICHTS [BVERFGE] 1, 17; Bundesverfassungsgericht [BVerfG] [Federal Constitutional Court] June 11, 1958, 8 EntsCheIdungen des Bundesverfassungsgerichts [BVERFGE] 28, 35; Bundesverfassungsgericht [BVerfG] [Federal Constitutional Court] Mar. 30, 1977, 44 ENTSCHEIDUNGEN DES Bundesverfassungsgerichts [BVerfGE] 249, 264; Bundesverfassungsgericht [BVerfG] [Federal Constitutional Court] Sept. 19, 2007, 119 ENTSCHEIdUngen DEs Bundesverfassungsgerichts [BVERFGE] 247, 264.

${ }^{25}$ Judgment of June 12, 2018 at para. 152.

${ }^{26} \mathrm{Judgment}$ of June 12, 2018 at para. 152.
} 
heed the right to form associations, ${ }^{27}$ and the red line the Federal Constitutional Court thereby draws against the European Court of Human Rights as a precautionary measure is clearly discernible.

The Senate then goes beyond this general statement and adds that a right to strike, and be it only for subsets of career civil servants:

[W] ould fundamentally reshape the understanding and regulations of the civil service. It would erode the principles of alimentation, of the duty of loyalty, of lifetime employment, and the principle that material rights and duties, including remuneration, must be regulated by the legislature. At the very least, it would require fundamental changes to these principles, which are essential to the functioning of the civil service. ${ }^{28}$

If a right to strike was permitted, there would be no more room to set remuneration standards via legislation, for instance. ${ }^{29}$ Once more, the Federal Constitutional Court emphasizes that a right to strike for civil servants "would interfere with the core ... structural principles guaranteed under Article 33(5)" of the Basic Law, such that the "obligation to observe the ban on strike action blocks the way to profound structural changes effected by the general legislation." 30

\section{Proportionality Test and the Establishment of Practical Concordance?}

The Senate in the end states its view that the status-based strike ban for career civil servants also does not disproportionately interfere with the guarantee of Article 9(3) of the Basic Law. ${ }^{31}$ The clash between the right to form associations and the traditional principles of the career civil service system is said to call for resolution "in accordance with the principle of practical concordance, which means that conflicting constitutional law positions must be assessed in terms of how they interact and ... be balanced in such a way that they are as effective as possible for all persons involved." 32 Under the approach of the Constitutional Court, however, it is hard to recognize how the right to form associations is being upheld to the greatest possible extent. Rather, Article 33(5) of the Basic Law asserts itself totally, ${ }^{33}$ thereby raising the question of why the Federal Constitutional Court does not simply join the Federal Administrative Court in directly limiting the scope of protection of Article 9(3) of the Basic Law.

Rather unconvincing is, furthermore, the Court's assessment that the impairment of Article 9(3) of the Basic Law does not impose a particularly heavy burden on career civil servants, supposedly for the reason that the right to strike is "only one element of the right to form lab[o]r coalitions." 34 The right to strike, along with the autonomy to engage in collective bargaining, indeed forms the very core of the freedom to form labor coalitions. Other partial guarantees that extend to labor association members, such as the right to be informed or the right to be represented by counsel, are- by comparison-relatively marginal. The statements that the right to form labor coalitions is not wholly relegated, and that the strike ban "does not render it completely ineffective," are therefore only partially correct. This applies especially when-as has happened in the past-public sector pay increases are regularly withheld from career civil servants or are extended to them only symbolically. This is the context in which one must read the Federal Administrative Court's decision on career

\footnotetext{
${ }^{27} \mathrm{Cf}$. Hebeler, supra note 15, at 371 ("[The] switches [are] set in such a way [that, if the tension between article $9(3)$ and article 33(5) of the Basic Law is not resolved,] the latter prevails.”)

${ }^{28}$ Judgment of June 12, 2018 at para. 153.

${ }^{29}$ Judgment of June 12, 2018 at paras. 153, 158.

${ }^{30}$ Judgment of June 12, 2018 at para. 153.

${ }^{31}$ Judgment of June 12, 2018 at paras. 156-162.

${ }^{32}$ Judgment of June 12, 2018 at para. 157 (emphasis added).

${ }^{33}$ Martin Stuttmann, Anmerkung, Neue Zeitschrift FÜr Verwaltungsrecht [NVwZ] 1137 (2018).

${ }^{34}$ Judgment of June 12, 2018 at para. 158 ("the [burden] ... is not unreasonable") (emphasis added).
} 
civil servants' right to strike, ${ }^{35}$ which sought to free the civil servants from their "defenseless predicament." 36

As the Second Senate emphasizes, various statutory provisions ${ }^{37}$ nevertheless compensate the impairment of the right to form labor coalitions by granting leading union federations the right to participate in rulemaking concerning career civil servant relations. Nevertheless, in the view of the Court, a "genuine co-decisional right" of labor unions when it comes to setting civil servant salaries would conflict with the principle of democracy embodied in Articles 20(1) ${ }^{38}$ and $20(2)^{39}$ of the Basic Law. ${ }^{40}$ The Second Senate also points to the principle of alimentation, explaining that it gives individual civil servants a right tantamount to a fundamental right to seek judicial review of the government's fulfilment of its duty in that regard and to compel it through litigation. Neither of these considerations, however, seem very convincing. There is no further discussion of why the principle of democracy should operate as a bar to greater union participation. A genuine conflict with the principle of democracy could only arise, however, if such determinations were to be made subject to the consent of labor unions. ${ }^{41}$ Strengthened participation rights alone-regardless of how these would have to be arranged - do not call into question the legislature's political prerogative and decision-making initiative. Further, post-facto judicial review of alimentation cannot be compared to having an opportunity to be involved in establishing decent working conditions from the outset.

It would have been more convincing had the Court followed the approach by the Federal Administrative Court ${ }^{42}$ and others ${ }^{43}$ and arrived at a practical concordance informed by article 33(4) of the Basic Law, ${ }^{44}$ whereby it might have narrowed the scope of the strike ban to "core-area career civil servants" 45 mainly engaged in exercising sovereign functions. Public school teachers in particular - the "marginal-area civil servants" who are the primary concern in practice-would not be covered by the ban on strikes in this case. In addition to affording greater weight to the fundamental right to form associations, this approach would have had the charm of being closer to the standards of the European Court of Human Rights, which this Article will consider shortly.

\footnotetext{
${ }^{35} 149$ BVERFGE 117. See also, Bundesverfassungsgericht [BVerfG] [Federal Constitutional Court] Mar. 24, 2015, 139 ENTSCHEIDUNGEN DES BUNDESVERFASSUNGSGERICHTS [BVERFGE] 64 (discussing unconstitutional under-alimentation).

${ }^{36}$ Stuttmann, supra note 33.

${ }^{37}$ E.g., Bundesbeamtengesetz [BBG] [Career Federal Civil Servants Act], July 17, 1953, BundesGesetzBlatt, Teil I [BGBL I] at 567, § 118; Gesetz zur Regelung des Statusrechts der Beamtinnen und Beamten in den Ländern [Beamtenstatusgesetz] [BeamtStG] [Act on the Regulation of the Law Concerning the Status of Career Civil Servants] June 17, 2008, BundesGesetzBlatT, Teil I [BGBL I] at 1020, $\$ 53$.

${ }^{38}$ Article 20(1) of the Basic Law reads: "The Federal Republic of Germany is a democratic and social federal state."

${ }^{39}$ Article 20(2) of the Basic Law reads: "All state authority is derived from the people. It shall be exercised by the people through elections and other votes and through specific legislative, executive and judicial bodies."

${ }^{40}$ Judgment of June 12, 2018 at para. 162.

${ }^{41}$ Timo Hebeler, Ausweitung der gewerkschaftlichen Beteiligung bei der Vorbereitung gesetzlicher Regelungen der beamtenrechtlichen Verhältnisse?, NeUE ZeITSCHRIFT FÜr VerwaltungsRecht [NVwZ] 1368 (2018).

${ }^{42} 149$ BVERWGE 117 (134).

${ }^{43}$ See Frauke Brosius-Gersdorf, Commentary, Kommentierung, in 2 GRUNDGESETZ art. 33, at para. 189 (Horst Dreier ed., 3rd ed. 2015); Gerit Armin Neuhäuser \& Partrick Christian Otto, Kein generelles Streikverbot für Beamte!, in DEUTSCHES Verwaltungsblatt 393, 397 (2016); Robert von Steinau-Steinrück \& Stephan Sura, (Noch) kein Streikrecht für Beamte, NZA 580, 582-83 (2014); Gunnar Folke Schuppert, Das beamtenrechtliche Streikverbot auf Dem Prüfstand 24 (2014); Paul Gooren, Das Ende des Beamtenstreikverbots, ZeITSCHRIFT FÜR BEAmTEnReCHT 400, 404-05 (2011); Gabriele BuchHoltz, Streiken im EuropÄISChen Grundrechtsgefüge 296, 443-445 (2014); Richard N. LAUER, DAS Recht des Beamten zum Streik 271 (2017); Claudia Schubert, Das Streikverbot für Beamte und das Streikrecht aus Art. 11 EMRK im Konflikt, 137 ARCHIV DES ÖFFENTLICHEN RECHTS [AöR] 92, 115-16 (2012) (discussing the need to amend the constitution); Christian Traulsen, Das Beamtenstreikverbot zwischen Menschenrechtskonvention und Grundgesetz, 68 Juristenzeitung [JZ] 65, 69-70 (2013). But see, e.g., Udo Di FAbio, DAs BEAMtenrechtliche StreikVerbot 58-59 (2012).

${ }^{44}$ Article 33(4) of the Basic Law reads: "The exercise of sovereign authority on a regular basis shall, as a rule, be entrusted to members of the public service who stand in a relationship of service and loyalty defined by public law."

${ }^{45}$ Judgment of June 12, 2018 at para. 158.
} 
In rejecting the possibility of such a functionally differentiating approach to strike law, the Second Senate points to the line-drawing difficulties inherent in resorting to the concept of sovereign powers or authority. ${ }^{46}$ Not only would it prove difficult to clearly determine when a particular service is an exercise of sovereign authority, but it would also be problematic to determine in the abstract whether a particular official was permitted to strike who, as a result of being reposted, reassigned, or transferred, for example, ended up performing some sovereign and some non-sovereign functions. Moreover, the Senate is of the opinion that a right to strike for "marginal-area civil servants" would jeopardize the guarantee of stable administration and performance of official functions even beyond the scope of Article 33(4) of the Basic Law.

Yet, line-drawing difficulties are generally a weak reason. ${ }^{47}$ The legal practitioner encounters them daily in many contexts, including, for instance, in Article 33(4) of the Basic Law, which-in spite of the line-drawing issue-is not obsolete. As a rule, line-drawing problems are manageable. The Federal Administrative Court in any case has convincingly explained what areas of administration pertain to the exercise of sovereignty. ${ }^{48}$ The notion that stable administration and governmental functions would no longer be ensured if "marginal-area civil servants" obtained a recognized right to strike is a mere assertion, one that is not even particularly plausible in view both of the many regular employees in public service and of the privatization of many public functions in recent years. ${ }^{49}$

Nevertheless, the Court does not fully block the path to a right to strike for "marginal-area civil servants" de lege ferenda. As the Federal Constitutional Court points out elsewhere in the judgment, a "right to strike, even for some groups of civil servants only ... at the very least ... would require fundamental changes" to the regulation by the legislature "of the material rights and duties including remuneration." ${ }^{0}$ The Court, therefore, apparently would not regard the legislative introduction of such a right to strike as entailing "structural changes to the regu-

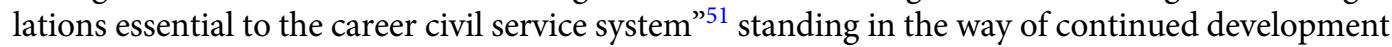
of career civil servant law. Conceivably, by hinting at the option of legislative change, the Senate has left itself an opening to react to the eventuality that the European Court of Human Rights would overturn its decision.

As a matter of what the future law should look like, the legislature has considerable leeway to provide "marginal-area civil servants" with more than a mere right to individual sympathetic participation in wage-related strikes. Proposals for corresponding statutory schemes are on the table. Despite the Federal Constitutional Court's holding, one rather conservative option would be, for instance, a "substantial expansion of trade unions' participation rights toward a negotiation model" that goes beyond what Section 118 of the BBG and Section 53 of the BeamtStG provide, as the Federal Administrative Court has already suggested. ${ }^{52}$ The same Court has already raised ${ }^{53}$ the possibility for the legislature to establish a negotiation and mediation model that would allow unions a parity-based participation, along the lines of the so-called Third Way fashioned by the

\footnotetext{
${ }^{46}$ Judgment of June 12, 2018 at para. 161; Hebeler, supra note 15, at 371; Stuttmann, supra note 33.

${ }^{47}$ See also Steinau-Steinrück \& Sura, supra note 43, at 582 ("ordinary legislation can be implemented ... as regards separating the domains").

${ }^{48} 149$ BVERWGE 117 (134-35) (discussing armed forces, police, other law enforcement agencies, the courts, tax administration, foreign service, and federal, state, and municipal administrative entities entrusted with planning and carrying out official actions and with sovereign oversight functions).

${ }^{49}$ See 149 BVERwGE 117 (135).

${ }^{50}$ Judgment of June 12, 2018 at para. 153 (emphasis added).

${ }^{51}$ Judgment of June 12, 2018 at paras. 119, 125.

${ }^{52} 149$ BVerwGE 117 (136). See also Schubert, supra note 43, at 109-10; UlRich BATtis, StreikVERBOT FÜR BEAMTE 37 (2013).

${ }^{53} 149$ BVerwGE 117 (136). See also Stefan Greiner, EMRK, Beamtenstreik und Daseinsvorsorge, DIE ÖFFENTLICHE VERWALTUNG [DÖV], 623, 625-26 (2013).
} 
Federal Labor Court for church institutions. ${ }^{54}$ Furthermore, despite the Federal Constitutional Court, "marginal-area civil servants" could be allowed to strike at least over the issue of salaries as a way of pressuring the other side to accept concrete demands. Career civil servants' salaries could be included as an issue in collective bargaining of public employment contracts "without endangering the balance of the regulatory structure in career civil service law." ${ }^{25}$ Not only could labor unions in which career civil servants are organized engage in collective bargaining, but career civil servants outside the domains of public administration covered under Article 33(4) of the Basic Law could also join strikes, as indicated by the link established through the principle of alimentation between collective agreements concerning public employees and the salaries of career civil servants. ${ }^{56}$

\section{Accounting for the ECHR and the Case-Law of the European Court of Human Rights}

Although the Federal Constitutional Court regards the European Convention on Human Rights domestically as having the force of a federal statute under Article 59(2) of the Basic Law, ${ }^{57}$ the Convention and the case-law of the European Court of Human Rights affect the interpretation of constitutional law because of what is referred to as the Basic Law's "openness" toward international law and, especially, because of the Basic Law's Article 1(2) ${ }^{58,59}$ This dimension of constitutional law is significant in light of the fact that the European Court of Human Rights in several proceedings against Turkey_in particular Demir and Baykara ${ }^{60}$ — has expanded the rights of public employees and —in Enerji Yapi-Yol Sen-declared that a blanket ban on strikes by public employees is contrary to the Convention. ${ }^{61}$ In the aftermath of those decisions, it was hotly debated whether the ban on strikes by career civil servants in Germany is contrary to the Convention, ${ }^{62}$ with the administrative courts

\footnotetext{
${ }^{54}$ Bundesarbeitsgericht [BAG] [Federal Labor Court] Nov. 20, 2012, NeUE ZeITSCHRIFT FÜr ARBEITSRECHT [NZA] 448, 463-464 (2013).

${ }^{55} 149$ BVerwGE 117 (137).

${ }^{56} 149$ BVerwGE 117 (137).

${ }^{57}$ Article 59(2) of the Basic Law reads

Treaties that regulate the political relations of the Federation or relate to subjects of federal legislation shall require the consent or participation, in the form of a federal law, of the bodies responsible in such a case for the enactment of federal law. In the case of executive agreements the provisions concerning the federal administration shall apply, mutatis mutandis.

${ }^{58}$ Article 1(2) of the Basic Law reads: "The German people therefore acknowledge inviolable and inalienable human rights as the basis of every community, of peace and of justice in the world."

${ }^{59}$ Judgment of June 12, 2018 at paras. 127-28; Bundesverfassungsgericht [BVerfG] [Federal Constitutional Court] Mar. 26, 1987, 74 ENTSCHEIdUNGEN DEs BundesverfassungsGerichts [BVERFGE] 358, 370; Bundesverfassungsgericht [BVerfG] [Federal Constitutional Court] Oct. 14, 2004, 111 ENTSCHEIDUNGEN DEs BundesverfassungsGerichts [BVERFGE] 307, 317; Bundesverfassungsgericht [BVerfG] [Federal Constitutional Court] Feb. 26, 2008, 120 ENTSCHEIDUNGEN DES BundeSVERFASSUNGSGERICHTS [BVERFGE] 180, 200-01; Bundesverfassungsgericht [BVerfG] [Federal Constitutional Court] Feb. 8, 2011, 128 ENTSCHEIDUNGEN DES BUNDESVERFASSUNGSGERICHTS [BVERFGE] 326, 367; Bundesverfassungsgericht [BVerfG] [Federal Constitutional Court] June 20, 2012, 131 ENTSCHEIDUNGEN DES BUNDESVERFASSUNGSGERICHTS [BVERFGE] $268,295$.

${ }^{60}$ Demir \& Baykara v. Turkey, App. No. $34503 / 97$ (Nov. 11, 2008), http://hudoc.echr.coe.int/eng?i=001-89558.

${ }^{61}$ Enerjy Yapi-Yol Sen v. Turkey, App. No. 68959/01 (Apr. 21, 2009), http://hudoc.echr.coe.int/eng?i=001-92267; Jürgen Bröhmer, Versammlungsfreiheit und Vereinigungsfreiheit, in 1 EMRK/GG KONKORDANZKOMMENTAR ZUM EUROPÄISCHEN UND DEUTSCHEN GRUNDRECHTSSCHUTZ, ch. 19, at paras. 106 (Oliver Dörr et al. eds., 2nd ed. 2013) (discussing the development of the case-law).

${ }^{62}$ See Jörg Polakiewicz \& Adriana Kessler, Das Streikverbot für deutsche BeamtInnen, NVwZ 841, 842 (2012) (discussing incompatibility with the ECHR); Monika Schlachter, Beamtenstreik im Mehrebenensystem, RECHT DER ARBEIT [RDA] 341,

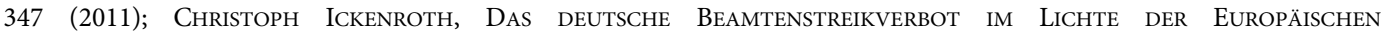
MensCHENRECHTSKONVENTION 164 (2016); LAUER, supra note 43, at 237; BuchHoltz, supra note 43, at 288-301; Gooren, supra note 43, at 404-05 (tending the same way); Stefan Werres, Der Einfluss der Menschenrechtskonvention auf das Beamtenrecht, DÖV 873, 879 (2011); Josef Franz Lindner, Dürfen Beamte doch streiken?, DÖV 305, 307-08 (2011)
} 
coming to divergent conclusions. ${ }^{63}$ The Federal Administrative Court, most prominently, held that the career civil servant strike ban is incompatible with Article 11 of the ECHR, but that in light of Article 33(5) of the Basic Law, it was for the legislature to strike a balance between the conflicting standards of the ECHR and the Basic Law under the principle of practical concordance. ${ }^{64}$

The Federal Constitutional Court, however, sees no conflict between the career civil servant strike ban constitutionally anchored in Article 33(5) of the Basic Law and Article 11 of the ECHR in the contours set by the case-law of the European Court of Human Rights. Beyond the concretely decided question of the strike ban in career civil service law, the decision also (1) specifies the guiding effect of the case-law of the European Court of Human Rights, (2) delineates the limits of the Basic Law's openness to the Convention, and (3) warrants conclusions about the institutional relationship between the Federal Constitutional Court and the European Court of Human Rights.

\section{Orientation and Guidance Function of the Case-Law of the European Court of Human Rights}

The Federal Constitutional Court has consistently held that decisions of the European Court of Human Rights are not only binding in individual cases under Article 46(1) of the ECHR, ${ }^{65}$ but they must also be duly considered within the domestic legal order. ${ }^{66}$ The strike ban decision builds upon this jurisprudential approach and grounds the authority of European Court of Human Rights decisions, on the one hand, in their "[at any rate de facto] direction and guidance function," ${ }^{67}$ and, on the other hand, in the notion of avoiding conflicts between domestic law and the international legal obligations of the Federal Republic of Germany. ${ }^{68}$ The Senate also emphasizes, following established constitutional case-law, that this approach does not imply a schematic adoption of European Court of Human Rights case-law, but rather that there is a need to situate the human rights considerations within the domestic constitutional order "in an active process (of acknowledgment)."69

\section{Contextualization}

The Senate develops new standards when it comes to the need for a contextualized reception of European Court of Human Rights decisions in proceedings to which the Federal Republic of Germany has not been a party. ${ }^{70}$ A correspondingly context-sensitive reception of judicial

(discussing conformity with the Convention); Anna-Bettina Kaiser, Streikrecht für Beamte—Folge einer Fehlrezeption?, 142 AöR 417 (2017); Jens Kersten, Neues Arbeitskampfrecht 26-27 (2012); Hinnerk Wißmann, Streikrecht für Beamte, ZEITSCHRIFT FÜR DAS JURISTISCHE STUdIUM 395, 400 (2011) (tending the same way).

${ }^{63}$ For an overview, see Neuhäuser \& Otto, supra note 43, at 394-95; Kaiser, supra note 62, at 429-430

${ }^{64} 149$ BVERwGE 117. See also Bundesverwaltungsgericht [BVerwG] [Federal Administrative Court] Feb. 26, 2015, NeUE ZeitsChrift FÜr VerwaltungsRecht [NVwZ] 811 (reaffirming the decision). But see Brosius-Gersdorf, supra note 43, at para. 190 (discussing criticisms); Christian Walter, Der Internationale Menschenrechtsschutz zwischen Konstitutionalisierung und Fragmentierung, 75 ZEITSCHRIFT FÜR AUSLÄNDISCHES ÖFFENTLICHES RECHT UND VÖLKERRECHT 753, 757-761 (2015) (differentiating).

${ }^{65}$ See Hans-Joachim Cremer, Entscheidung und Entscheidungswirkung, in EMRK/GG, KONKORDANZKOMMENTAR, supra note 61 , ch. 32 , at para. 110; HeIKo SAUER, STAATSRECHT III $\$ 7$, at paras. 11-12 (5th ed. 2018).

${ }^{66}$ See cases cited supra note 59.

${ }^{67}$ Judgment of June 12, 2018 at para. 129 (citing 128 BVERFGE 326 (368); 111 BVERFGE 307 (320) (giving an even more expansive holding)). In panel decisions one finds, going further, the concept of a "normative guidance function." See Bundesverfassungsgericht [BVerfG] [Federal Constitutional Court] Sept. 19, 2006, NeUE JURISTISCHE WOCHENSCHRIFT [NJW] 499, 501; Bundesverfassungsgericht [BVerfG] [Federal Constitutional Court] Dec. 13, 2006, NeUE ZEITSCHRIFT FÜR VerwaltungsRecht [NVwZ] 808, 811-12; Bundesverwaltungsgericht [BVerwG] [Federal Administrative Court] Dec. 16, 1999, 110 Entscheidungen des Bundesverwaltungsgerichts [BVerwGE] 203, 210; Andreas Voßkuhle, Der europäische Verfassungsgerichtsverbund, NVwZ 1, 4 (2010).

${ }^{68}$ Judgment of June 12, 2018 at para. 129 (citing 111 BVERFGE 307 (328); Bundesverfassungsgericht [BVerfG] [Federal Constitutional Court] Oct. 26, 2004, 112 EnTSCHEIdungen DEs Bundesverfassungsgerichts [BVERFGE] 1 (25-26)).

${ }^{69}$ Judgment of June 12, 2018 at para. 131 (citing 128 BVERFGE 326 (370)).

${ }^{70}$ Judgment of June 12, 2018 at para. 132. 
decisions is required to do justice to the peculiarities of judicial law-making: Courts do not make law in the abstract, but rather generate law while deciding concrete disputes. ${ }^{71}$ Regarding the orientation and guidance function of the case-law of the European Court of Human Rights, this peculiarity is amplified by the fact that the decision will always have been rendered in light of the legal order of an individual state party to the Convention. In this regard, the European Court of Human Rights undertakes case-dependent and case-specific elaborations of the ECHR. ${ }^{72}$ Accordingly, the Federal Constitutional Court has already emphasized in its Görgülü decision that the Convention's legal protections are set up to operate through the determination of concrete individual disputes between the applicants and the state parties to the Convention, and that it is therefore the task of domestic courts to "fit in" the decisions of the European Court of Human Rights into the domestic legal order and its doctrines. ${ }^{73}$ The proportionality test is the main-but not exclusive-point at which the broader context of a government action that has been challenged before the European Court of Human Rights may be crucial to a decision and thus to its reception. When the European Court of Human Rights case-law is transferred into German law, the Federal Constitutional Court thus duly lays the focus upon considering the concrete facts of the case, the legal-cultural background, and the specific peculiarities of the German legal order. ${ }^{74}$

\section{Relativization}

Unconvincing, by contrast, is the Senate's general relativization of the guiding effect of European Court of Human Rights decisions in connection with the required contextualization. It justifies this by emphasizing that the ECHR, unlike European Union law, does not take precedence of application (Anwendungsvorrang) over domestic law. ${ }^{75}$ It is, however, far from clear why one should conclude from the absence of a rule of prioritization that the substantive significance of European Court of Human Rights decisions should be diminished in general when interpreting the ECHR. The hierarchy of legal rules only becomes relevant at a later stage regarding the limits of complying with the case-law of the European Court of Human Rights. Such examination, however, presupposes the consideration of the substantive requirements of the ECHR, because the hierarchy question only arises in case of a conflict between German law and the Convention. The Federal Constitutional Court's holding is therefore unconvincing when the Court states that the main purpose of the guiding effect is "to identify ... principal values enshrined in the Convention and address them." This approach fails both in view of the fact that the Court elsewhere has emphasized that the ECHR applies in Germany "as interpreted by the European Court of Human Rights," 76 and also in light of the practice of the German courts and of the Federal Constitutional Court itself, which attach far greater importance to the case-law of the European Court of Human Rights than the term "principal values" would suggest. This approach does not do justice to the importance of the European Court of Human Rights as an authoritative arbiter of the meaning of the $\mathrm{ECHR}^{77}$ endowed with the competence to interpret and substantiate the meaning of the Convention. ${ }^{78}$ Moreover, reducing the inquiry to the principal values of the

\footnotetext{
${ }^{71}$ See Mehrdad Payandeh, Judikative Rechtserzeugung 210-219, 247-248, 465-470 (2017) (providing a detailed discussion).

${ }^{72}$ SAUER, supra note 65, at para. 21.

${ }^{73} 111$ BVERFGE 307 (327).

${ }^{74}$ Judgment of June 12, 2018 at para. 132.

${ }^{75}$ Judgment of June 12, 2018 at para. 132.

${ }^{76} 111$ BVERFGE 307 (325-26).

${ }^{77} 149$ BVERWGE 117 (129-30); Walter, supra note 64, at 756-57.

${ }^{78}$ Marten Breuer, Art. 46 Verbindlichkeit und Vollzug der Urteile, in EMRK 663, at para. 45 (Ulrich Karpenstein \& Franz C. Mayer eds., 2nd ed. 2015); SAUER, supra note 65, at para. 11a; Cremer, supra note 65, at para. 118; Jens Meyer-Ladewig \& Kathrin Brunozzi, Art. 46 Verbindlichkeit und Durchführung der Urteile, in EMRK 695, at para. 16 (Jens Meyer-Ladewig et al. eds., 4th ed. 2017) (going so far as to call it "judge-made law").
} 
jurisprudence contravenes what the Federal Constitutional Court's openness toward international law is meant to achieve, which is to avoid - if possible - conviction of the Federal Republic of Germany by the European Court of Human Rights for a violation of the ECHR.

\section{Operationalization}

In applying these standards to the case at hand, the Federal Constitutional Court does not find the strike ban for career civil servants to be in violation of the ECHR. ${ }^{79}$ The Court begins by going through the relevant precedents of the European Court of Human Rights. In doing so, it is, however, rather unusual that the Court, when addressing Demir and Baykara, dedicates more space to the separate concurring opinion of four judges than to the majority's holding. Because the majority decision confirms the importance of the right to form associations even for civil servants, while the separate concurring opinion emphasizes the unique features of the civil service and the divergent arrangements of the ECHR states, the latter is of course more in line with the Federal Constitutional Court's approach. From the point of view of the Senate's argument, this emphasis is understandable. But by representing the case this way, the Court gives the impression that it wants to dilute the significance of the majority opinion and not respect the way the votes came down inside the Grand Chamber of the European Court of Human Rights.

The case-law of the European Court of Human Rights makes clear that while the European Court considers the right to strike to be protected under Article 11(1) of the ECHR and as encompassing public sector employees, it does not regard the right to strike as guaranteed in an absolute manner. The European Court is rather prepared to view substantively grounded restrictions as justified. In the challenges brought against Turkey, in which the European Court of Human Rights held that Article 11 of the ECHR had been violated, the Court criticized what in its view was a lack of convincing grounds for justifying the impairment of the right to form labor coalitions measured against the standard of necessity in a democratic society pursuant to Article 11(2) of the ECHR. In Demir and Baykara, the European Court of Human Rights regards a mere reference to the privileged position of civil servants as insufficient justification for curtailing the right to strike. ${ }^{80}$ And it stresses in Enerji Yapi-Yol Sen that in Turkey, the strike ban applies to the whole government workforce, not just to certain groups of public sector employees. ${ }^{81}$ The Federal Constitutional Court rightly points out that the European Court of Human Rights does not regard the right to strike as an end in itself, but rather as a means for labor unions to make themselves heard and thereby protect their interests. ${ }^{82}$ This approach opens up the possibility of a differentiated assessment under Convention law, taking into account that career civil servants and their representatives have other ways to pursue their interests, such as participatory rights and the right to seek judicial review of alimentation claims under Article 33(5) of the Basic Law. ${ }^{83}$ Against this backdrop, the Federal Constitutional Court engages in detailed reasoning, including the examination of the case-law of the European Court of Human Rights, in order to conclude that the strike ban is in accordance with Article 11 of the ECHR. ${ }^{84}$ The Senate explains that the strike ban in Germany is not an expression of privileges held by career civil servants, and that it serves more than to preserve the functioning of public administration and secure the rights of third parties.

\footnotetext{
${ }^{79}$ Judgment of June 12, 2018 at paras. 163-88.

${ }^{80}$ Demir, App. No. $34503 / 97$ at para. 168.

${ }^{81}$ Enerjy Yapi-Yol Sen, App. No. 68959/01 at para. 32. See also Kaiser, supra note 62, at 435-36 (discussing the ambiguities in the translation of the passage from the French-language decision); OLIVER LEPSIUS, RelationEN 53 (2016) (criticizing the translation of the decision in NZA 1423 (2010)).

${ }^{82}$ Enerjy Yapi-Yol Sen, App. No. 68959/01 at para. 24. See also, Wilson, National Union of Journalists and Others v. The United Kingdom, App. No. 30668/96 (July 2, 2002) at para. 45, https://hudoc.echr.coe.int/ (exemplifying the formerly even greater emphasis on this aspect in European Court of Human Rights jurisprudence).

${ }^{83} \mathrm{Judgment}$ of June 12, 2018 at paras. 175, 183. See also Hebeler, supra note 15, at 372 (expressing skepticism).

${ }^{84} \mathrm{Judgment}$ of June 12, 2018 at paras. 173-180.
} 
Instead, it is proper to be evaluated as it interrelates with the principles of fiduciary duty, lifetime appointment, and alimentation, which are the hallmarks of the career civil servant relationship. ${ }^{85}$

The Federal Constitutional Court's discussion is, in general, convincing. The Court highlights the particularities of German career civil service law, which could at least plausibly justify an impairment of the right to strike for career civil servants. In doing so, the Senate convincingly distinguishes between Turkish law, the dispute-specific context of the relevant European Court of Human Rights precedents, and the particularities of German public sector employment law as follows: The European Court of Human Rights decisions with regard to Turkey cannot be transferred sight unseen into the German legal context, because the strike ban in Turkey affected all government workers, whereas the German ban applies only to duly appointed and sworn career civil servants, leaving those in employer-employee relationships unaffected. ${ }^{86}$ Because there is no uniform European approach, neither to the overall contours of public sector employment law nor to the question of government workers' right to strike, ${ }^{87}$ there is much to be said for recognizing a wide margin of appreciation for the member states in this regard. ${ }^{88}$

At the same time, the Federal Constitutional Court's reasoning is highly results-oriented: It marginalizes certain statements of the European Court of Human Rights that could be read as calling into question the Federal Constitutional Court's position, in particular, the emphasis on the substantial significance of the right to strike with regard to the right to form labor coalitions, or the limited margin of appreciation of member states with regard to justifications for impairments of this right. The Federal Constitutional Court ignores the European Court of Human Rights' noticeable skepticism toward a purely status-related strike ban, as well as its positive inclination towards a functional differentiation under the criterion of being engaged in the exercise of sovereign powers, ${ }^{89}$ as is implicit in the second sentence of Article 11(2) of the ECHR.

\section{Limits of Openness Towards the Convention}

Given the Federal Constitutional Court's assumption that the strike ban in career civil service law is compatible with the ECHR, it is surprising that the Court takes the occasion for making fundamental statements about the limits of the German Constitution's openness towards the law of the Convention. Building on previous case-law, the Senate first elaborates that European Court of Human Rights precedents may only be considered to the extent that the German law that must be interpreted and applied by German courts allows for such consideration in a methodologically sound manner. ${ }^{90}$ In this context, the Federal Constitutional Court also refers—-systematically, but not very convincingly, because the issue is not one of juridical methods but rather of substantive boundaries - to the absolute limit that is the immutable core of Germany's constitutional identity pursuant to Article 79(3) of the Basic Law. ${ }^{91,92}$ This limitation for the reception of

\footnotetext{
${ }^{85}$ Judgment of June 12, 2018 at para. 181.

${ }^{86}$ See Lindner, supra note 62, at 307-08; KERSTEN, supra note 62, at 26; Jürgen Treber, Arbeitskampfmaßnahmen der Arbeitnehmer, in Schaub ArbeitsRechts-HANDBuCh $\$ 192$, at para. 40 (Martina Ahrendt, et al. eds., 17th ed. 2017); Schlachter, supra note 62 (expressing skepticism in light of the way the European Court of Human Rights picks up on function rather than status).

${ }^{87}$ See Kaiser, supra note 62 , at $422-424$.

${ }^{88}$ See also LAUER, supra note 43 , at 263-64 (taking the same position).

${ }^{89}$ Abbo Junker, Kooperation oder Konfrontation der obersten Instanzen in Deutschland und Europa, EUROPÄISCHE ZEITSCHRIFT FÜr ARBEITSRECHT 304, 316 (2018); LAUER, supra note 43, at 261

${ }^{90}$ Judgment of June 12, 2018 at para. 133 (citing 111 BVERFGE 307 (329); 128 BVERFGE 326 (371)). See also Bundesverfassungsgericht [BVerfG] [Federal Constitutional Court] Oct. 22, 2014, 137 ENTSCHEIDUNGEN DES BUNDESVERFASSUNGSGERICHTS [BVERFGE] 273, 321.

${ }^{91}$ Article 79(3) of the Basic Law reads: "Amendments to this Basic Law affecting the division of the Federation into Länder, their participation in principle in the legislative process, or the principles laid down in Articles 1 and 20 shall be inadmissible."

${ }^{92}$ See SAUER, supra note $65, \$ 9$, at para. 43; Albert Ingold, Die verfassungsrechtliche Identität der Bundesrepublik Deutschland, 140 AöR 1 (2015) (providing a detailed discussion); Thomas Wischmeyer, Nationale Identität und
} 
international law was originally developed with regard to European Union law. It finds its origins in the Lisbon judgment ${ }^{93}$ and was subsequently elaborated on in later opinions. ${ }^{94}$ The Court had already referred to it as a limit for the application of the ECHR and of European Court of Human Rights precedents in its Sicherungsverwahrung (protective custody) decision. ${ }^{95}$ Second, the Court emphasizes that an interpretation warranted by the principle of openness to international law must not restrict the protection of fundamental rights under the Basic Law. This boundary of reception is important, particularly when it comes to multipolar fundamental rights relationships. ${ }^{96}$ Third, the Court points to the need to ensure that European Court of Human Rights standards are fitted into the German legal system "as carefully as possible."

As applied to the strike ban, these three kinds of limits to reception do not seem to fit very well. In light of the open texture of Article 33(5) of the Basic Law, loosening the ban on strikes by career civil servants would neither overstep the confines of juridical methodology ${ }^{98}$ nor would it hamper the fundamental rights of third parties. ${ }^{99}$ And the requirement that the ECHR is to be carefully fitted into domestic law does not stand in the way of examining Convention law standards, but rather would guide that examination. The problem of the strike ban is more a question of whether a possible Convention-based standard determining that career civil servants are entitled to go on strike is substantively compatible with the Basic Law. This raises the hitherto not-yet-conclusivelydetermined question of the substantive constitutional limits of consideration of European Court of Human Rights precedents. On this question, the reasoning of the Görgülü decision has been ambivalent, if not outright contradictory, ${ }^{100}$ and the Court's Sicherungsverwahrung decision has

Verfassungsidentität. Schutzgehalte, Instrumente, Perspektiven 140 AöR 415 (2015); SVEN SIMON, GRENZEN DES BundeSVERFASSUNGSGERICHTS IM EUROPÄISCHEN INTEGRATIONSPROZESS, 96 et seq. (2016); MONIKA POlZIN, VERFASSUNGSIDENTITÄT (2018).

${ }^{93}$ Bundesverfassungsgericht [BVerfG] [Federal Constitutional Court] June 30, 2009, 123 ENTSCHEIDUNGEN DES BundeSVERFASSUNGSGERICHTS [BVERFGE] 267, 344.

${ }^{94}$ See, e.g., Bundesverfassungsgericht [BVerfG] [Federal Constitutional Court] Dec. 15, 2015, 140 ENTSCHEIDUNGEN DES BundESVERFASSUNGSGERICHTS [BVERFGE] 317 (regarding European arrest warrants); Bundesverfassungsgericht [BVerfG] [Federal Constitutional Court] Jan. 14, 2014, 134 ENTSCHEIDUNGEN DES BundesverfassungSGERICHTS [BVERFGE] 366 (regarding the outright monetary transaction policy of the European Central Bank); Bundesverfassungsgericht [BVerfG] [Federal Constitutional Court] June 21, 2016, 142 ENTSCHEIDUNGEN DES BundesverfassungsGeriCHTS [BVERFGE] 123 (same).

${ }^{95} 128$ BVERFGE 326 (371).

${ }^{96} J$ udgment of June 12, 2018 at para. 134 (citing 137 BVerfGE 273 (329)); Wolfgang Hoffmann-Riem, Kontrolldichte und Kontrollfolgen beim nationalen und europäischen Schutz von Freiheitsrechten in mehrpoligen Rechtsverhältnissen, ZEITSCHRIFT FÜR EUROPÄISCHE GRUNDRECHTE [EUGRZ] 492 (2006); Gertrude Lübbe-Wolff, Der Grundrechtsschutz nach der Europäischen Menschenrechtskonvention bei konfligierenden Individualrechten, in NACHDENKEN ÜBER STAAT UND RECHT 193 (Martin Hochhuth ed., 2010); Heiko Sauer, Bausteine eines Grundrechtskollisionsrechts für das europäische Mehrebenensystem, EUGRZ 195, 198 (2011).

${ }^{97}$ Judgment of June 12, 2018 at para. 135.

${ }^{98}$ See Neuhäuser \& Otto, supra note 43, at 399 (making the same point); Angelika Nußberger, Auswirkungen der Rechtsprechung des Europäischen Gerichtshofs für Menschenrechte auf das deutsche Arbeitsrecht, RdA 270, 273 (2012); Polakiewicz \& Kessler, supra note 62, at 844; ICKENROTH, supra note 62, at 188; LAUER, supra note 43, at 279; BuchHoltz, supra note 43, at 59; Werres, supra note 62, at 880; Detlef Hensche, Der Streik im öffentlichen Dienst, in ArbeitsKampfrecht 502, at para. 87 (Wolfgang Däubler ed., 4th ed. 2018). But see Thomas Rothballer, Zulässigkeit des Beamtenstreiks?, NZA 1119, 1121 (2016) (articulating a different view); Achim Seifert, Recht auf Kollektivverhandlungen und Streikrecht für Beamte, KRITISCHE VIERTELJAHRESSCHRIFT FÜR GESETZGEBUNG UND RECHTSWISSENSCHAFT 357, 375-76 (2009); Di FABIO, supra note 43, at 59; Traulsen, supra note 43, at 69 (providing a faltering reference to the constitutional stature of the strike ban based on an interpretation open to international law that pertains especially to constitutional law); Nils Schaks, Anmerkung zum Urteil des BVerwG vom 27.2.2014, Az.: 2 C 1/13 (Streikverbot für Beamte), NVwZ 743, 744 (2014); Schubert, supra note 43, at 115; Lindner, supra note 62, at 306; Kersten, supra note 62, at 32.

${ }^{99}$ But see BuCHHOLTZ, supra note 43 , at 335-343 (differentiating).

${ }^{100} 111$ BVERFGE 307. See also Mehrdad Payandeh, Konventionswidrige Gesetze vor deutschen Gerichten, DÖV 382, 385 (2011) (discussing the decision). 
also not significantly elucidated the problem either. ${ }^{101}$ The two decisions rather vaguely described the substantive limits without establishing a clear benchmark for when and under what circumstances the German Constitution does not comply with the ECHR. The Sicherungsverwahrung decision is, however, the source of the reference to the limit imposed by the immutable core of Germany's constitutional identity under Article 79(3) of the Basic Law, ${ }^{102}$ to which the strike ban decision refers in determining the applicable standards. ${ }^{103}$ Yet, when applying the constitutional standards to the case at hand, the Court does not take up this standard again, but rather dips back into language from the Görgülü decision-which was not reiterated in subsequent decisions on the effect of the ECHR ${ }^{104}$ _invoking "fundamental constitutional principles." Because the Senate assumed that the strike ban was compatible with the ECHR, the question of the limits of considering the Convention was not relevant for the decision, so there was no need to clarify whether the strike ban constitutes a "fundamental constitutional principle" not susceptible of more than one interpretation. ${ }^{105}$ In spite of this, the Court concludes by remarking that "[n] onetheless, many arguments would support this."106

The determination that "fundamental constitutional principle[s]" constrain consideration of the standards of the ECHR makes it clear that in the case of a collision between the Convention and the Basic Law, the latter will not always prevail; it is only when there is a conflict with specially qualified constitutional principles that Convention standards are barred from consideration. The ECHR thus is accorded a privilege other international treaties are not. The Federal Constitutional Court, pointing to Article 1(2) of the Basic Law, had already indicated as much in its Treaty Override decision. ${ }^{107}$ At the same time, however, it is not quite clear whether the Federal Constitutional Court regards these fundamental constitutional principles as identical—or as congruent - with those encompassed by the concept of the German constitutional identity-which was developed primarily as a limit to European integration-or to the observance of European Union law. The differing terminology hints that the Federal Constitutional Court assumes looser boundaries in regard to the ECHR than it does in the context of European integration. But the Court in any case leaves for itself the option of declaring that constitutional standards are "fundamental principles" beyond the limits of the constitutional identity doctrine, and thereby immunizing constitutional law against international legal standards. This interpretation is also supported by the Federal Constitutional Court's allusion to the possibility that the strike ban could be one such fundamental constitutional principle, because neither the strike ban nor the constitutional guarantee of the career civil service system are within the scope of the guarantee of Article 79(3) of the Basic Law. ${ }^{108}$ Certainly, the precise constitutional limit of consideration of the Convention cannot be stated in general on the basis of the constitutional identity or the notion of fundamental constitutional principles. Therein lies what must be a considerable part of the appeal for the Federal Constitutional Court of resorting to formulations like these: Eventually, the Court will be called upon to ultimately determine where the boundary lies in an individual case.

\footnotetext{
${ }^{101} 128$ BVERFGE 326. See also Mehrdad Payandeh \& Heiko Sauer, Menschenrechtskonforme Auslegung als Verfassungsmehrwert, JURISTISCHE AUSBILDUNG 289, 295-96 (2012) (discussing the decision).

${ }^{102} 128$ BVERFGE 326 (371).

${ }^{103}$ Judgment of June 12, 2018 at para. 133.

${ }^{104}$ That said, the phrase does appear in the Lisbon judgment. 123 BVERFGE 267 (400-401). The phrase also appears in the Treaty Override decision. Bundesverfassungsgericht [BVerfG] [Federal Constitutional Court] Dec. 15, 2015, 141 ENTSCHEIDUNGEN DES BUNDESVERFASSUNGSGERICHTS [BVERFGE] 1, 24.

${ }^{105} \mathrm{Judgment}$ of June 12, 2018 at paras. 172, 176.

${ }^{106} \mathrm{Judgment}$ of June 12, 2018 at para. 172.

${ }^{107} 141$ BVERFGE 1 (32); Mehrdad Payandeh, Grenzen der Völkerrechtsfreundlichkeit, NJW 1279, 1281 (2016) (criticizing the indicated privileging of the Convention).

${ }^{108}$ See Monika Jachmann-Michel \& Anna-Bettina Kaiser, Art. 33 GG, in 2 Kommentar Zum Grundgesetz 807, at paras. 29, 41 (Peter Michael Huber \& Andreas Voßkuhle eds., 7th ed. 2018); UlRich BATTIS, BundesbeamtengeseTz 26, at para. 11 (5th ed. 2017).
} 
Even though the Federal Constitutional Court does not conclusively determine whether the strike ban in career civil service law is a fundamental constitutional principle such that conflicting European Court of Human Rights standards would be barred from consideration, the mere suggestion that it might be is rather alarming. Even if one comprehended the strike ban as a traditional principle of the professional career civil service system within the meaning of Article 33(5) of the Basic Law, it is unconvincing to go on and characterize it as a "fundamental principle" and suppose that that characterization shuts the door on other interpretations suggested by the ECHR and the European Court of Human Rights. Doubts arise from the facts that the strike ban is not expressly laid down in Article 33(5) of the Basic Law and that the provision conversely looks to "development" of the law of public sector employees. ${ }^{109}$ Doubts arise also, and especially so, because Article 33(5) merely requires that "the law governing the public service shall be regulated and developed with due regard to the traditional principles of the professional civil service." 110 Even if one agrees with the Federal Constitutional Court's assumption that some essential principles deserve not just "due regard" but rather strict observance, ${ }^{111}$ it is doubtful whether such observance would also apply to the strike ban, because, although it is connected to the basic principles of the duties of loyalty and care, it cannot be equated with them. ${ }^{112}$ Furthermore, the basic principles of the career civil service system are not absolute guarantees, but are-as most constitutional provisions are-subject to impairment in order to accommodate other constitutional principles. ${ }^{113}$ Therefore, it is hard to understand why restrictions of those constitutional principles dealing with the career civil service should be categorically excluded. Quite the contrary, it seems rather plausible that such restrictions could be regarded as legitimate in order to accommodate the right to form labor coalitions or the constitutional principle of the openness to international law that calls for due regard for the standards set by the European Court of Human Rights and the ECHR. Even if the Federal Constitutional Court is skeptical of differentiating approaches to the career civil servant strike ban, it would not be out of line with core principles of constitutional law to limit the strike ban to career civil servants that are actually performing functions of state authority. ${ }^{114}$ Differentiating in this fashion would also be in line with the European Court of Human Rights inasmuch as the Strasbourg Court has recognized that a strike ban based on service function can affect particular groups of public servants. ${ }^{115}$

\section{The Relationship Between the Federal Constitutional Court and the European Court of Human Rights}

The decision on the career civil servant strike ban constitutes yet another building block within the institutional architecture of fundamental rights protection in Europe. The Federal Constitutional Court upholds its generally open approach towards the Convention, which results in an extensive consideration of the standards of the ECHR and of the case-law of the European Court of Human Rights. It attaches to the Convention regime a significance within the domestic legal and constitutional order far greater than the parity with federal statutes to which international treaties are formally entitled in domestic law. In doing so, the Federal Constitutional Court rightly does not constrain itself to uncritical, unilateral adoption of Convention standards. Instead,

\footnotetext{
${ }^{109}$ But see KERSTEN, supra note 62, at 28 (taking a differentiating approach).

${ }^{110}$ Emphasis added by the authors.

${ }^{111} 119$ BVerfGE 247 (262); Hans D. Jarass \& Bodo Pieroth, Grundgesetz FÜr die Bundesrepublik Deutschland 702, at para. 52 (15th ed. 2018) (discussing limits and criticisms).

${ }^{112} \mathrm{Cf}$. Neuhäuser \& Otto, supra note 43, at 396-97; Gooren, supra note 43, at 403.

${ }^{113}$ Bundesverfassungsgericht [BVerfG] [Federal Constitutional Court] Nov. 16, 1992, 87 ENTSCHEIDUNGEN DES Bundesverfassungsgerichts [BVERFGE] 348, 355-56; Brosius-Gersdorf, supra note 43, at para. 177; JARASS \& Pieroth, supra note 111, at para. 45; Hensche, supra note 98, at para. 27.

${ }^{114}$ See also Neuhäuser \& Otto, supra note 43, at 397; Polakiewicz \& Kessler, supra note 62, at 844.

${ }^{115}$ Enerjy Yapi-Yol Sen, App. No. 68959/01 at para. 32.
} 
its reception of the case-law of the European Court of Human Rights is context-sensitive and must be regarded as part of a judicial dialogue with the Strasbourg Court over the compatibility of the strike ban for career civil servants with the Convention, a question that-contrary to widely-held opinion within legal scholarship—-has not yet been determined by the European Court of Human Rights with sufficient clarity. At the time of this writing, it is impossible to tell whether the German strike ban is compatible with ECHR standards, at least if one accepts the premise that this question is ultimately to be determined by the European Court of Human Rights. Therefore, the Federal Constitutional Court rightly points out that, "at this time," a conflict between German law and the ECHR does not exist. ${ }^{16}$ Both the context-sensitive reception of the case-law of the European Court of Human Rights and the substantive arguments as to the compatibility of the German strike ban with the Convention are, in general, convincing. ${ }^{117}$ It remains to be seen whetherand if so, to what extent-the European Court of Human Rights will accept the Federal Constitutional Court's approach. ${ }^{118}$

Not so friendly towards the Convention is, however, that the Federal Constitutional Court downplays the significance of the European Court of Human Rights' case-law by limiting its domestic reception to the "principal values" embodied in those decisions. Moreover, unnecessarily confrontational, and not convincing in substance, is the Court's hint that if the European Court of Human Rights were to declare the strike ban to be in violation of the ECHR, the German Court might not go along. The Federal Constitutional Court has recently made similar allusions in its Chefarzt (chief physician) decision. ${ }^{119}$ In doing so, the Senate is applying a strategy with regard to its relationship with the European Court of Human Rights very similar to decisions on the limits of European integration, whereby the Karlsruhe Court signals to the Court of Justice of the European Union what specific kinds of interpretations of European Union law by the Luxembourg Court the Federal Constitutional Court will regard as constitutionally acceptable. ${ }^{120}$ A dialogue, including one on substantive issues, between member state and European Union courts is whole-heartedly welcome. Overt threats of non-compliance, however, are not. The fact that the Federal Constitutional Court has regularly been willing to cooperate with both European Courts and has yet to decline to follow the lead of either the Court of Justice of the European Union or the European Court of Human Rights might be reassuring, but it cannot completely overplay the confrontational tone of the German Constitutional Court.

\footnotetext{
${ }^{116}$ Judgment of June 12, 2018 at para. 163. But see Enerjy Yapi-Yol Sen, App. No. 68959/01 at para. 172 (applying the operative term gegenwärtig [at this time] to German law).

${ }^{117}$ But see Wienbracke, supra note 19 , at 654.

${ }^{118}$ The Federal Constitutional Court could not refer the issue directly to the European Court of Human Rights because the Federal Republic of Germany has not ratified Protocol No. 16, which allows the contracting parties' respective highest courts to seek an advisory opinion from the European Court of Human Rights. Whether and in what manner the Court would have done so is a separate issue. See Jörg Gundel, Erfolgsmodell Vorabentscheidungsverfahren?, EUROPARECHT 609 (2015).

${ }^{119} 137$ BVerfGE 273 (329). See also Claus Dieter Classen, Anmerkung, JZ 199 (2015) (discussing the decision). But attacks on the Federal Constitutional Court's very deferential stance toward religious societies have begun coming not out of Strasbourg, but rather, Luxembourg. See, e.g., Case C-414/16, Egenberger v Evangelisches Werk für Diakonie und Entwicklung e.V. (Apr. 17, 2018), http://curia.europa.eu/juris/liste.jsf?num=C-414/16; Opinion of Advocate General Wathelet, Case C-68/17, IR v. JQ (May 31, 2018), http://curia.europa.eu/juris/document/document.jsf?docid=202426\&doclang=EN. On the entire issue, see generally Michael Lysander Fremuth, Das letzte Amen ist noch nicht gesprochen, EuZW 723 (2018).

${ }^{120}$ See, e.g., 123 BVERFGE 267 (406-431) (hinting at a European Union primary law interpretation and directing this, at least obliquely and maybe even primarily, at the European Court of Justice); Bundesverfassungsgericht [BVerfG] [Federal Constitutional Court] Apr. 24, 2013, 133 EnTSCHEIdungen des BundesverfassungSGerichts [BVerfGE] 277, 316 (expecting a narrow interpretation of extensive European Court of Justice precedents on the scope of the first sentence of Article 51(1) of the Charter of Fundamental Rights of the European Union); 140 BVERFGE 317 (355-366) (construing the Framework Decision on European arrest warrants in accord with Article 1(1) of the Basic Law - the guarantee of human dignityand a corresponding expectation that the European Court of Justice shares that interpretation).
} 


\section{Conclusion}

The Federal Constitutional Court not only recognizes that the career civil servant strike ban is protected by Article 33(5) of the Basic Law, but it also enlarges this constitutional principle in a manner that hardly leaves any room for conflicting fundamental rights such as the freedom to form associations. The Court rejects differentiating approaches to career civil servants' right to take collective action-in particular, any approach that would not focus on the status of civil servants but rather on whether they are engaged in performing sovereign functions. Even if the decision leaves a back door open with regard to "fundamental modifications," it still leads to an unnecessary restriction of possible legislative action and makes any prospect of reform more difficult. When it comes to the consideration of the ECHR and the case-law of the European Court of Human Rights, the decision contains further specifications and developments that, while not fundamentally calling into question the Court's friendly stance toward international law, are still not fully convincing. The Federal Constitutional Court's indication that it might not comply with a demand of the European Court of Human Rights even to loosen the career civil servant strike ban sends a rather uncooperative signal to the Strasbourg Court. The Federal Constitutional Court thereby increases the not to be underestimated danger that domestic courts, especially in other European states, will invoke the reservations advanced by the Federal Constitutional Court in order to justify not following determinations made by European courts. Within the network of European constitutional courts, ${ }^{121}$ the Federal Constitutional Court is not only responsible for protecting Germany's fundamental rights and the German Constitution, but also for safeguarding the rule of law and the authority of the European courts, especially in times like these.

\footnotetext{
${ }^{121}$ Voßkuhle, supra note 67 , at 1.
} 